\title{
GRID TYPE IMPACT ON THE RESULTS OF THE VOLUME OF FLUID METHOD \\ IN THE FREE SURFACE FLOW CALCULATIONS AROUND SHIP HULL
}

DOI 10.2478/ntpe-2018-0019

\author{
MSc. Eng. Karol Sugalski \\ Maritime University of Szczecin,Poland \\ Ing. Tomáš Skrúcaný, PhD \\ University of Zilina, Slovak Republic
}

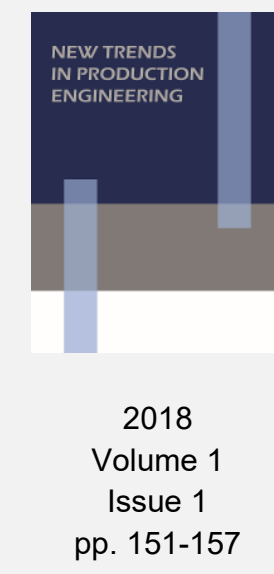

\begin{abstract}
This article presents results of the free surface flow around ship hull on two different types of computational grid. Each type of mentioned grid has its own advantages and disadvantages in particular cases, mostly in one phase simulation. Omitting cases with capitation, there is no free surface involved in one phase simulation. Multiphase simulations are crucial in the ship design process and optimization. Recreating free surface on the triangular mesh causes difficulties, in contrast to the hexahedral meshes, where calculated surface is more aligned to the physical border of the fluids. In this paper, results from the triangular mesh were compared to results from hexahedral mesh. Conclusions about triangular meshes in two phase simulation are presented. The computational fluid dynamic toolbox OpenFOAM is used to perform calculations of the total resistance of work boat in calm water.
\end{abstract}

Keywords: ship, simulation, design, optimization, OpenFOAM

\section{INTRODUCTION}

Two distinct approaches exists during design of a ship hull shape and its hydrodynamic features. Utilizing analytical formulas and statistical data is the first one, which is also a starting point for the more sophisticated, experimental approach. Values of the resistance and main dimensions gathered from the formulas, are enough to create a valid hull with suitable engine. Outcome of this approach will be a vessel very similar in shape to this standing behind specific formulas, for example Savitsky (Suska, 2010) or Holtrop and Mennen (Watson, 1998). Limitation of this approach arise, when designed ship should differ from base vessel included in formulas.

Towing tank tests and related experiments defines second approach. All vital characteristics, such as resistance, ship-propeller interaction or speed will become known after experiments (Dudziak, 2008; Michalski, 2013). This is only way to design a prototype shape. Towing tank experiments are expensive, therefore plenty of designs are based on serial hulls. Many test and models have to be prepared to obtain good results. Instead of towing tank tests, numerical experiments are done to minimize costs of design.

Numerical experiments gained popularity due to constantly increasing computer's power. These experiments are based on solving Navier-Stoke's equations of fluid motion. Several methods are possible (Jaworski, 2005; Lomax et al., 2001), some with simplifications, some are more sophisticated, but eventually, force acting on submerged body is known.

Computational fluid dynamic calculations are sensitive to user input and setup. One has to be aware of factors, that can change results significantly (Blazek, 2005). Among others, factors that affect the results are: insufficient description of the phenomena, inappropriate turbulence model, grid resolution (Ferziger and Perić, 2002; Jaworski, 2005). Grid dependency test is a standard procedure in a CFD calculations (Abramowski and Sugalski, 2017; Kim et al., 2017). At least two grid sizes are compared to check behavior of results. According to (Gryboś, 1998), results should be independent of grid type when utilize finite volume method. Mentioned method is implemented in the OpenFOAM toolkit used in this work. 
Base for this study was a bulbous bow optimization of a workboat. It is an experimental approach in a design process, briefly described above. Results of similar experiments are often published, only specific software and geometry are different. In a work of (Pacuraru and Domnisoru, 2017) barge resistance using RANSE method is presented. Calculation of resistance using RANSE and LES turbulence model of a planing hull is shown in (De Marco et al., 2017). These studies together with author's study are examples of numerical towing tank experiments.

In the following work, hexahedra and tetrahedral meshes have been compared in term of hull resistance in the finite volume and interface capturing method.

\section{EXPERIMENT SETUP}

Dimensions and coefficients of a scaled model are shown in Table 1. Model was tested with the scale factor $\lambda=20$. Desired speed of the ship was $10 \mathrm{knots}$, which correspond to the velocity of $1.15 \mathrm{~m} / \mathrm{s}$ in model scale.

Table 1.

Ship model data.

\begin{tabular}{cccccccc}
\hline $\mathbf{L}_{w l} \mathbf{~ m}$ & $\mathbf{B ~} \mathbf{~ m}$ & $\mathbf{T ~} \mathbf{~ m}$ & $\mathbf{C}_{\mathbf{b}}$ & Wet. surface $\mathbf{~ m}^{\mathbf{2}}$ & $\mathbf{F r}_{\mathbf{r}}$ & $\mathbf{R e}_{\mathbf{e}}$ & $\mathbf{V ~ m} / \mathbf{s}$ \\
\hline 1.452 & 0.6 & 0.1425 & 0.425 & 0.9385 & 0.305 & $1.6 \cdot 10^{6}$ & 1.15 \\
\hline
\end{tabular}

Overall size of the computational domain was prepared as the function of the length of model (Abramowski and Sugalski, 2017; Kim et al., 2017) Fig. 1. Boundaries of the domain should be far enough to minimize gradient changes of selected variables. Otherwise special treatment of boundaries is needed. Other experiment setup and simplifications: calm water test, domain with symmetry plane, hull fixed in space. Results of the resistance obtained during test were scaled with standard ITTC 1978 procedure.

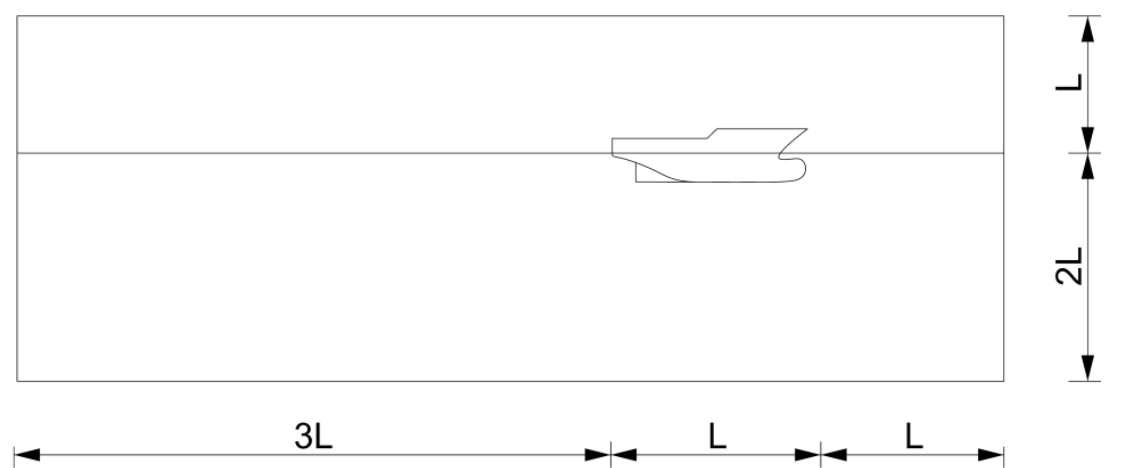

Fig. 1. Dimensions of the computational space.

\section{NUMERICAL MODEL}

Volume of Fluid method has been used to capture the interface between two phases. Properties of those phases has been set to the values which describe air and water. Properties are shown in Table 2 .Pressure inside the computational domain has been set to correspond to the sea level pressure. Hydrostatic pressure has been applied to the water. Simulation has been considered as a deep water simulation.

Table 2.

Properties of fluids during simulation.

\begin{tabular}{cccc}
\hline $\begin{array}{c}\text { Air density } \\
\mathbf{k g} / \mathbf{m}^{3}\end{array}$ & Water density $\mathbf{k g} / \mathrm{m}^{3}$ & $\begin{array}{c}\text { Kinematic viscosity of air } \\
\mathbf{m}^{2} / \mathbf{s}\end{array}$ & $\begin{array}{c}\text { Kinematic viscosity } \\
\text { of water } \mathbf{~ m}^{2} / \mathbf{s}\end{array}$ \\
\hline 1 & 998 & $1.48 \cdot 10^{-5}$ & $1.14 \cdot 10^{-6}$ \\
\hline
\end{tabular}

$\mathrm{K}-\omega$ turbulence model has been used to model turbulences involved in the flow. Special treatment of the mesh near hull surface has been made, to satisfy the $\mathrm{Y}^{+}$condition. Newtonian fluid model has been selected to both phases. Both water and air have been considered as vicious and 
uncompressible. Incompressible equation of mass conservation and momentum used in simulation are shown below (1), (2) (Ferziger and Perić, 2002):

where:

$$
\begin{gathered}
\nabla(\boldsymbol{V})=0 \\
\frac{\partial \boldsymbol{V}}{\partial t}+\nabla(\boldsymbol{V} \boldsymbol{V})=\nabla^{2}(\boldsymbol{V})-\frac{1}{\rho} \nabla(p \boldsymbol{I})+\boldsymbol{f}
\end{gathered}
$$

$\boldsymbol{V}$ is the velocity vector,

$\rho$ is the density,

$v$ is the kinematic viscosity,

$p$ is the pressure,

$I$ - unity tensor and

f - body forces.

Third (3) equation is added to resolve free surface, it is a transport equation of scalar $\alpha$. This value distinguish between phases.

$$
\frac{\partial \alpha}{\partial \mathrm{t}}+\nabla(\alpha \boldsymbol{V})=0
$$

\section{MESH}

Two types of mesh has been considered in this study. Shapes of cells used to create meshes are shown in Fig. 2. First, based on tetrahedron elements with prism near the hull of the vessel. Meshes based on tetrahedron are capable to recreate very complex geometries without losing any information of given shape.
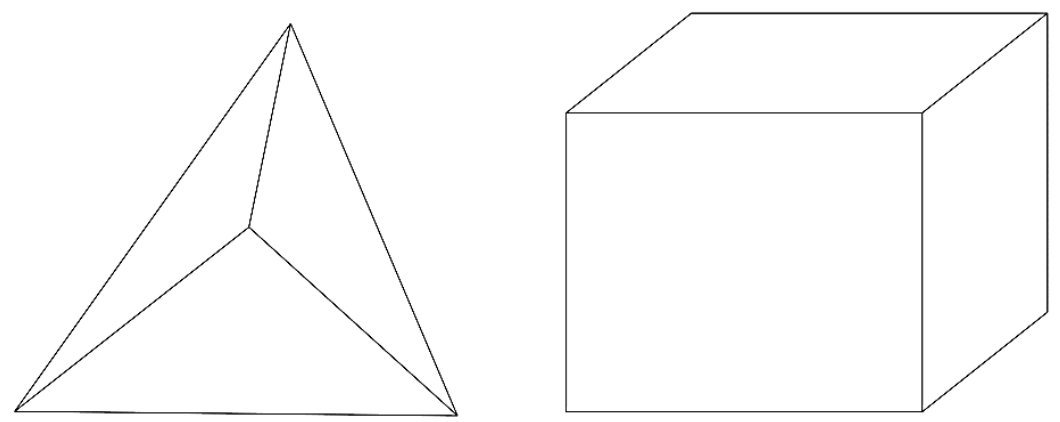

Fig. 2. Types of computational cell. Left - tetrahedron, right - hexahedron.

Second type of used mesh is based on hexahedral cells. One disadvantage of the hexahedral mesh is inability to create curved surfaces, ship hull for example. Meshing algorithm delivered with OpenFOAM will move individual vertices of cells to match given shape. As a result of this action, polyhedral elements are created Fig. 3. Additional care is needed when solving equations (1), (2) and (3) on mesh with polyhedral elements.

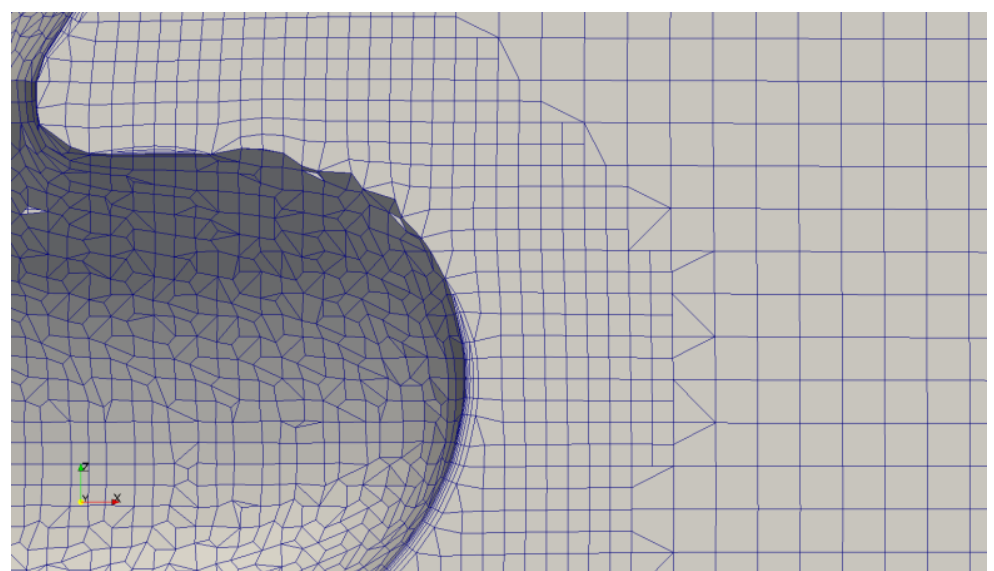

Fig. 3. Hexahedral mesh near bulbous bow. Prisms and polyhedral elements visible. 
Fragments of each types of grid are presented below. Tetrahedral mesh (Fig. 4) has more cells, but they are distributed more randomly than in hexahedral case (Fig. 5).

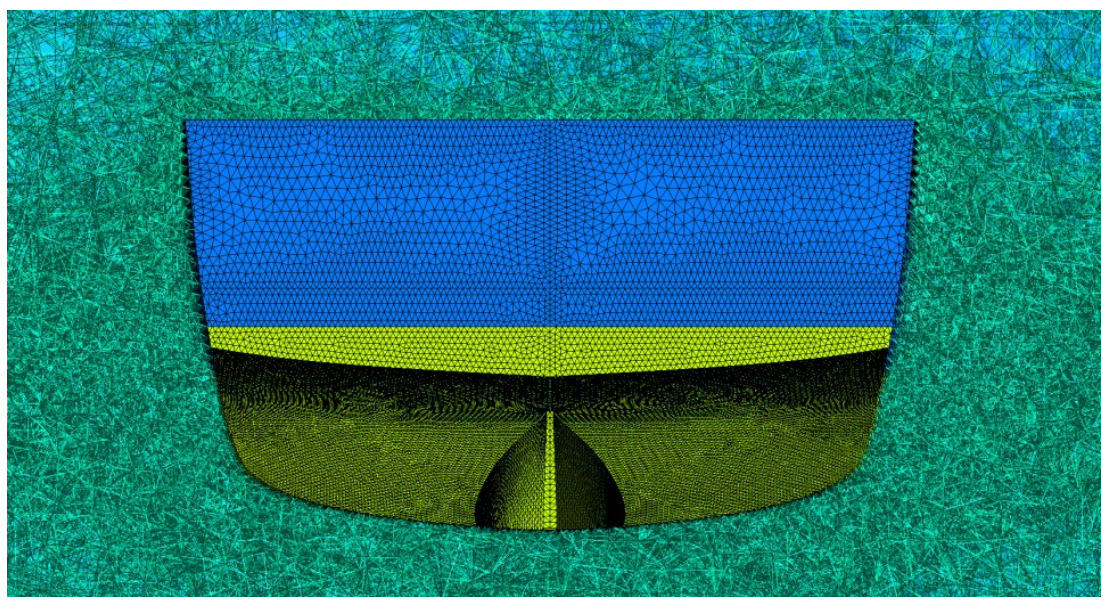

Fig. 4. Tetrahedral mesh around hull.

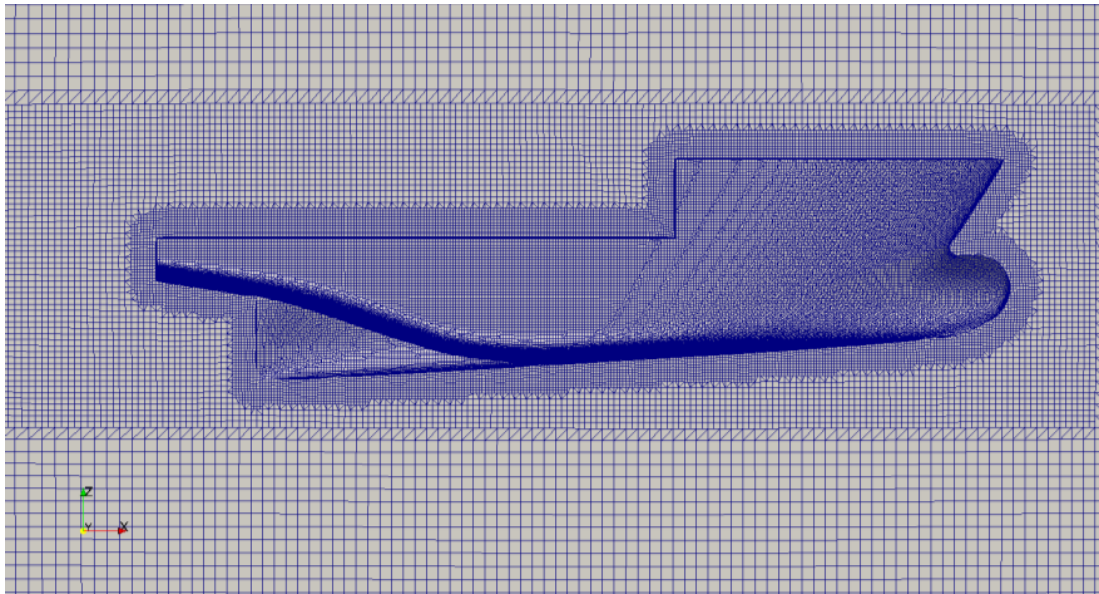

Fig. 5. Hexahedral mesh.

Refined zones of cells are crucial in multiphase simulations, because resistance is dependent on wave shape. Shape of the interface is only valid if cells are small in compare to the hull.

\section{RESULTS}

Results for the hexahedral mesh are presented in the Fig. 6. Resistance from the simulation based on the tetrahedral mesh are shown in the Fig. 7. To acquire value of total resistance presented in Table 3, algebraic averaging has been made.

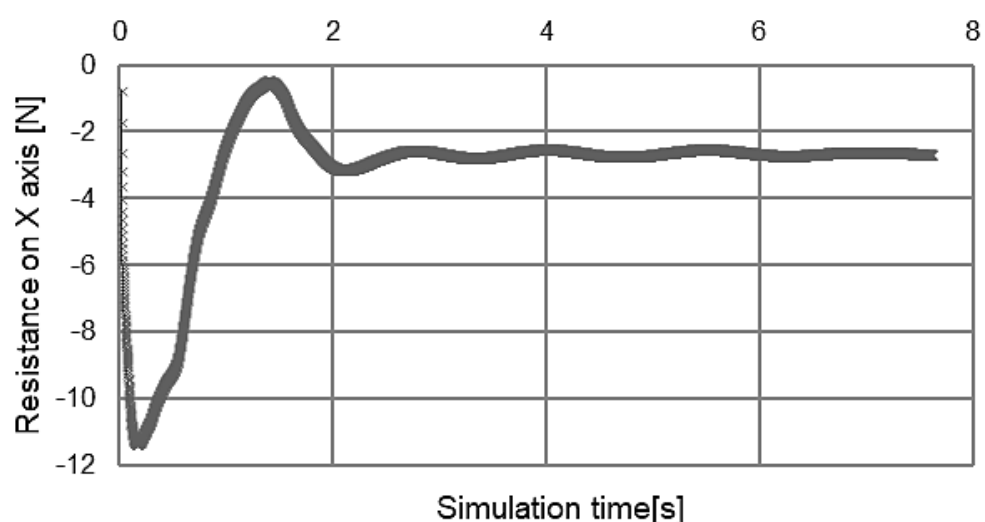

Fig. 6. Resistance results for the hexahedral mesh. Half of the hull. 


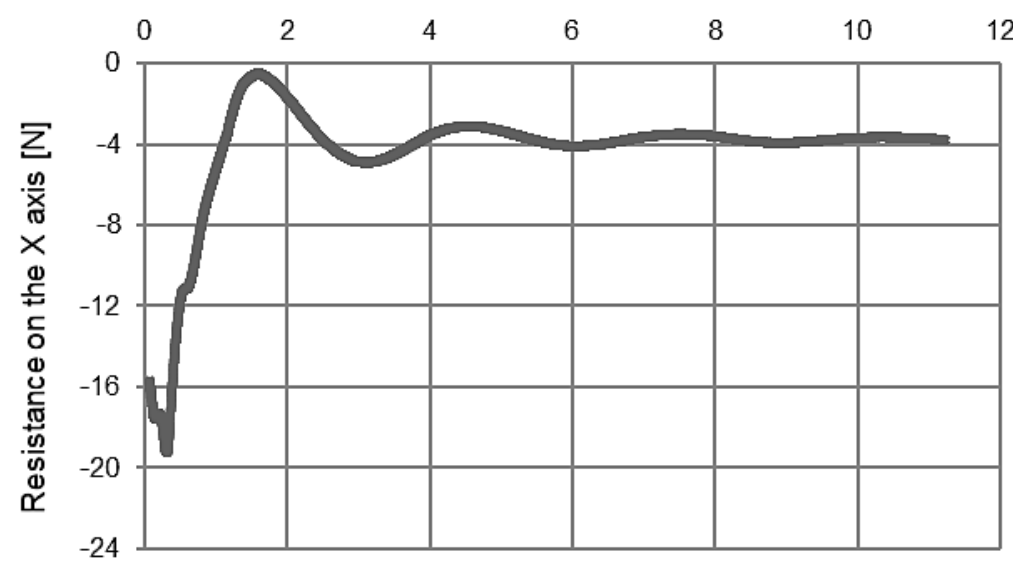

Simulation time [s]

Fig. 7. Resistance results for the tetrahedral mesh. Half of the hull.

There is a slight difference between results and this depends on the grid type. Value of the resistance on the tetrahedral grid is bigger than on the hexahedral. After translating results to the effective power and brake power, difference become even more bigger, as shown in Table 3. Further studies will be carried out to catch nature and origin of this differences.

Table 3.

Comparison of the results.

\begin{tabular}{|c|c|c|c|}
\hline & \multicolumn{2}{|c|}{ Mesh type } \\
\hline & & $\begin{array}{l}\text { Tetrahedral with } \\
\text { prism }\end{array}$ & $\begin{array}{l}\text { Hexahedra with } \\
\text { polyhedral }\end{array}$ \\
\hline \multicolumn{2}{|c|}{ Resistance value from calculation $\mathrm{N}$} & 5.89 & 7.25 \\
\hline \multirow{2}{*}{ ITTC 1978} & Effective power kW & 198.9 & 262.15 \\
\hline & Brake power kW & 526.16 & 693.4 \\
\hline
\end{tabular}

Wave elevation shown in Fig. 8 is not smooth. It was impossible to draw contour lines of waves, like in the Fig. 9.

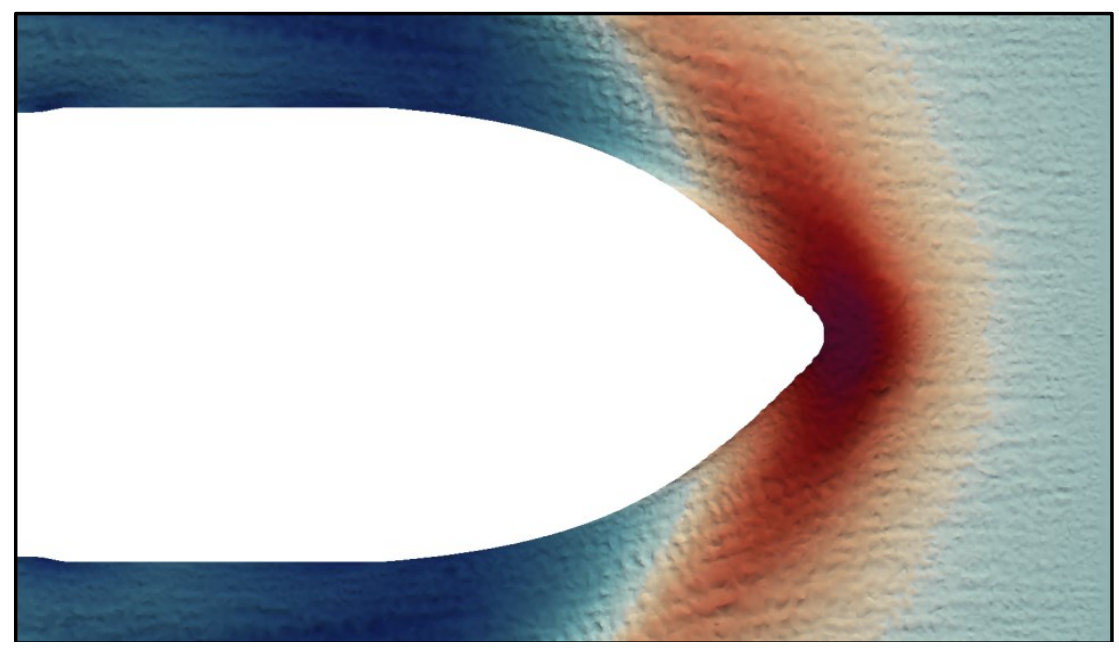

Fig. 8. Jagged surface of water. Tetrahedral mesh. 


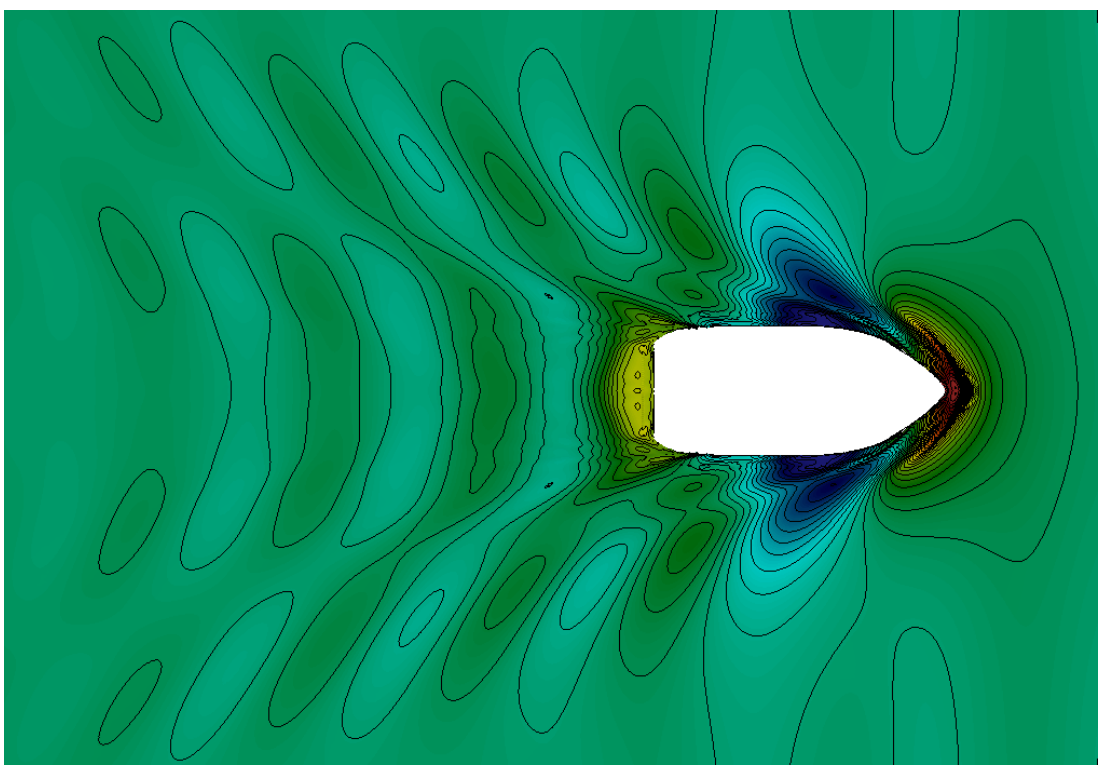

Fig. 9. Smooth surface of water. Hexahedral mesh.

\section{CONCLUSIONS}

Mesh prepared with tetrahedron elements maps given geometry without deviations. Tetrahedral mesh is capable of reproducing sharp edges of geometry while hexahedral will lose information about given shape (Fig. 3). It is very hard to maintain refined zone in the vicinity of the free surface while using tetrahedral mesh elements. Sudden changes in the volume of the computational cells leads to the local instabilities of the interface capturing method. Hexahedral elements can be easily set to certain size, therefore solution of the free surface is smooth (fig) and converge faster. It is impossible to refine tetrahedral elements in one direction. Such feature is demand in multiphase flows, near the interface of fluids. As a result, mesh generated with tetrahedral elements contains more computational cells than hexahedral mesh. Nevertheless, simulations based on hexahedral mesh needs more time to finish. This is due to more faces belong to each computational cell in a hexahedral element than in tetrahedral, consequently, more surface integration is performed in the solver (Blazek, 2005; Ferziger and Perić, 2002). In this study, values of the resistance from the tetrahedral mesh was higher in comparison to the hexahedral mesh. Wave system calculated on the tetrahedral mesh was very jagged and inappropriate for further post processing.

\section{REFERENCES}

Abramowski, T., and Sugalski, K. (2017). Energy saving procedures for fishing vessels by means of numerical optimization of hull resistance. Scientific Journals of the Maritime University of Szczecin 121, 19-27.

Blazek, J. (2005). Computational Fluid Dynamics: Principles and applications. (Elsevier).

De Marco, A., Mancini, S., Miranda, S., Scognamiglio, R., and Vitiello, L. (2017). Experimental and numerical hydrodynamic analysis of a stepped planing hull. Applied Ocean Research 64, 135-154.

Dudziak, J. (2008). Teoria okrętu (Gdańsk: Fundacja Promocji Przemysłu okrętowego i Gospodarki Morskiej).

Ferziger, J.H., and Perić, M. (2002). Computational Methods for Fluid Dynamics. (Berlin: Springer-Verlag).

Gryboś, R. (1998). Podstawy mechaniki płynów (Wydawnictwo Naukowe PWN).

Jaworski, Z. (2005). Numeryczna mechanika płynów w inzynierii chemicznej i procesowej (Warszawa: Akademicka Oficyna Wydawnicza EXIT).

Kim, Y.-C., Kim, K.-S., Kim, J., Kim, Y., Park, I.-R., and Jang, Y.-H. (2017). Analysis of added resistance and seakeeping responses in head sea conditions for low-speed full ships using URANS approach. International Journal of Naval Architecture and Ocean Engineering 9, 641-645.

Lomax, H., Pulliam, T.H., and Zingg, D.W. (2001). Fundamentals of Computational Fluid Dynamics. (Berlin: Springer-Verlag). 
Michalski, J.P. (2013). Podstawy teorii projektowania okrętów (Gdańsk: Wydawnictwo Politechniki Gdańskiej).

Pacuraru, F., and Domnisoru, L. (2017). Numerical investigation of shallow water effect on a barge ship resistance. (Romania).

Suska, W.L. (2010). Motorówki i małe kutry motorowe - wypornościowe, półwypornościowe/półślizgowe i ślizgowe. (Gdańsk: Fundacja Promocji Przemysłu okrętowego i Gospodarki Morskiej).

Watson, D.G.M. (1998). PRACTICAL SHIP DESIGN (Elsevier).

Date of submission of the article to the Editor: 06/2018

Date of acceptance of the article by the Editor: 08/2018 